\title{
Adsorption of Lead, Zinc, and Nickel lons from Wastewater Using Coriander Seeds as an Adsorbent
}

\author{
Hibatallah Jamil Shamkhi' ${ }^{1}$ Tamara Kawther Hussein ${ }^{1 *}$ \\ 1 Department of Environmental Engineering, College of Engineering, Mustansiriyah University, Baghdad, Iraq \\ * Corresponding author's e-mail: tamarahussein@uomustansiriyah.edu.iq
}

\begin{abstract}
This research focused on using coriander seeds as low cost adsorbent to remove heavy metals ions such as lead, zinc, and nickel from wastewater. Different parameters were studied to obtain the best results, such as $\mathrm{pH}$, contact time, adsorbent dosage, concentration of initial metals and agitation speed. The highest results were obtained at pH 6, 105 min contact time, $1 \mathrm{~g} / 100 \mathrm{ml}$ dosage, $50 \mathrm{mg} / 1$ initial concentration of metal ions and $200 \mathrm{rpm}$ agitation speed at temperature $25 \pm 2{ }^{\circ} \mathrm{C}$, which were $95.926 \%, 89.799 \%$ and $79.255 \%$ for lead, zinc and nickel ions, respectively. The results were also categorized as the Langmuir and Freundlich models, and found that the Freundlich isotherm fit the experimental data better than the Langmuir isotherm. The pseudo-second order was shown to have a high degree of fitness based on kinetic data. The adsorbent was characterized using a variety of techniques, including Fourier transform infrared spectroscopy (FTIR), Field Emission Scanning Electron Microscope (FESEM).
\end{abstract}

Keywords: Coriander seeds, adsorption, heavy metals, isotherm model, wastewater, kinetic model.

\section{INTRODUCTION}

Environmental pollution is one of humanity's most important problems. In recent years, it has increased at an unprecedented rate, reaching incredible proportions in terms of its impact on living things [Osińska, 2017; Faisal et al., 2011]. Heavy metals constitute one of the most common contaminants in wastewater. Heavy metal contamination is a serious environmental issue that has a significant effect on both the aquatic and terrestrial ecosystems due to their toxicity, nondegradability, and bioaccumulation [Yadav et al., 2020]. Mining, electroplating, chemical synthesis, paper production, and pesticide manufacturing all discharge metals into the environment in the form of mine tailings or effluents [Al-Obaidy et al., 2016]. Heavy metals have a density greater than $5 \mathrm{~g} / \mathrm{cm}^{3}$. The aquatic environment of Iraq has been severely impacted by heavy metals [Anna et al., 2015]. Because of their hazardous effects, the environmental protection agencies classify several toxic metals such as copper, nickel, zinc, cadmium, and lead as priority pollutants [Mohan,
2014]. Lead is a very harmful chemical that affects the environment and causes a variety of health problems. Lead poisoning can induce encephalopathy, kidney damage, and gastrointestinal problems. The maximum amount allowed in drinking water is $0.1 \mathrm{mg} / \mathrm{l}$, according to environmental rules [Kavand et al., 2014]. Zinc is also an important micronutrient, although it can induce acute or chronic toxicity if consumed in excess and it can cause depression, nausea, diarrhea, tiredness, and restlessness. World health organization (WHO) limits the amount of zinc in drinking water to $5.0 \mathrm{mg} / 1$ [Chatterjee et al., 2017]. Nickel is an important element that is necessary in tiny amounts for human health. It can, however, create health problems such as allergies, blood and heart abnormalities, chronic bronchitis, and - in high concentrations or for long periods of time - even cancer. In drinking water, the amount of nickel permitted is $0.1 \mathrm{mg} / 1$ [Ray et al., 2018].

Heavy metals like $\mathrm{Pb}^{+2}, \mathrm{Ni}^{+2}$ and $\mathrm{Zn}^{+2}$ ions are common in the wastewater from industries like electroplating, electronics, battery production, rubber factories, and paints [Malakahmad 
et al., 2016]. Ion exchange, chemical precipitation, electrochemical extraction, and adsorption are all prevalent methods for extracting heavy metal ions from wastewater; however, adsorption may be the best option due to its high efficiency, low cost, and ease of use [Mahanty et al., 2020; Jia et al., 2019]. Tea waste [ForoughiDahr et al., 2015], seed shells [Ergüvenerler et al., 2020], coriander seed [Ouass et al., 2017], coffee husks [Rodiguez et al., 2018] potato peels [Mohammed and Salim, 2017] and others have been studied as potential low cost heavy metal adsorbents.

Coriander (Coriandrum Sativum) is a common, taxonomically categorized medicinal herb that belongs to the Apiaceae family and its finely ground seeds are a major ingredient of curry powder, an effective antioxidant [Zeković et al., 2016]. Coriander is a tropical crop that may be cultivated in a variety of environments. Coriandrum sativum is grown commercially in India, Morocco, Poland, the United States of America, and Russia, among other places [Rao and Kashifuddin, 2012]. Coriander is a herb with all of the properties required for a food product. Its fruit has a sweet and aromatic aroma, and its seeds have stimulant, antipyretic, and antithelmintic properties. Vomiting, digestive diseases, bleeding piles, eye infections, and rheumatism are all treated with its fruit. The presence of essential oils, the quantity of which ranges from 0.1 percent to 0.3 percent in the seeds, is responsible for the fragrant fragrance and pleasant aromatic taste [Abdou Said et al., 2021]. The coriander seed powder was used as an adsorbent for $\mathrm{Pb}^{+2}, \mathrm{Zn}^{+2}$ and $\mathrm{Ni}^{+2}$ ions from industrial effluent because of its non-toxic nature. The influence of several operational factors, such $\mathrm{pH}$, adsorbent dose, contact time, agitation speed and initial metal ions concentration, as well as FESEM, FTIR, isothermal and kinetic models were investigated.

\section{MATERIALS AND METHODS}

\section{Adsorbent material}

Coriander seeds (Coriandrum sativum) were purchased from a herbal store in Baghdad, Iraq. The coriander seeds were washed several times with tap water and then with distilled water to remove impurities such as sand and dust, after which the coriander seeds are dried in an oven at $180{ }^{\circ} \mathrm{C}$ for two hours, ground with an electric grinder to obtain powder and then passed through sieve of diameter $425 \mu \mathrm{m}$ for use in experiments. Figure 1 shows the coriander seeds before grinding and as powder

\section{Adsorbate}

The heavy metals used in adsorption experiments $\left(\mathrm{Pb}\left(\mathrm{NO}_{3}\right)_{2}, \quad \mathrm{Zn}\left(\mathrm{NO}_{3}\right)_{2} \cdot 6 \mathrm{H}_{2} \mathrm{O}, \quad\right.$ and $\left.\mathrm{Ni}\left(\mathrm{NO}_{3}\right)_{2} \cdot 6 \mathrm{H}_{2} \mathrm{O}\right)$ were supplied from scientific equipment offices in Bab Al-Moatham markets, Baghdad, Iraq. In order to prepare the stock solution at a concentration of $(1000 \mathrm{mg} / \mathrm{l})$ by dissolving the calculated amount of $\mathrm{Pb}\left(\mathrm{NO}_{3}\right)_{2}$, $\mathrm{Zn}\left(\mathrm{NO}_{3}\right)_{2} \cdot 6 \mathrm{H}_{2} \mathrm{O}$, and $\mathrm{Ni}\left(\mathrm{NO}_{3}\right)_{2} \cdot 6 \mathrm{H}_{2} \mathrm{O}$ in $1000 \mathrm{~L}$ of distilled water to be used in the experiments. The mass of these metals required to achieve the concentration was calculated according to Eq. (1) [Qassim, 2013]:

$$
W=V \times C o \times \frac{M \cdot w t}{A t . w t}
$$

where: $W$ : weight of heavy metals, $V$ : Volume of solution (1), $C_{o}$ : Heavy metal ion concentration in solution at the initiation $(\mathrm{mg} / \mathrm{l})$,

M.wt: Molecular weight of heavy metal salt $(\mathrm{g} / \mathrm{mol})$,

At.wt: Atomic weight of $\mathrm{Pb}^{+2}, \mathrm{Ni}^{+2}, \mathrm{Zn}^{+2}$ ions $(\mathrm{g} / \mathrm{mole})$.

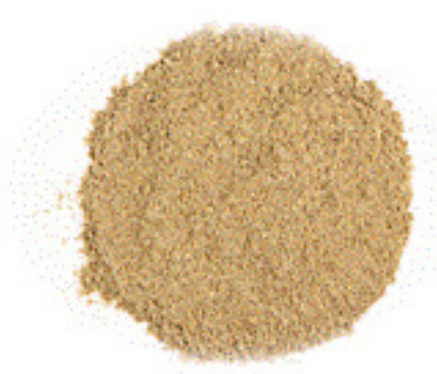

Figure 1. Coriander seeds before grinding and as powder 


\section{Experimental work}

The adsorption tests were carried out to find the best $\mathrm{pH}$, agitation speed, contact time, adsorbent diameter size, absorbent dosage, mineral elements concentration for removing lead, nickel, and zinc ions from wastewater. Conical flasks with the volume of $250 \mathrm{ml}$ were filled with $100 \mathrm{ml}$ of heavy metal solutions of known concentration. The $\mathrm{pH}$ was measured by a $\mathrm{pH}$ meter (WTW- 3110, Germany), the wastewater $\mathrm{pH}$ in each flask was adjusted by adding $0.1 \mathrm{M} \mathrm{NaOH}$ or $0.1 \mathrm{M} \mathrm{HCl}$ to obtain the desired $\mathrm{pH}$ value. Each flask was filled with a known weight of sorbent material, then placed in a shaker (Type Heidolph unimax 2010, Germany) and the mixture was agitated continuously for the specified time at temperature $25 \pm 2^{\circ} \mathrm{C}$. The withdrawn samples were filtered by using a filter paper (Whatman $12.5 \mathrm{~cm}$ ) and then an Atomic Absorption Spectrophotometer (AAS) (Type, A-shimadzuaa-7000f, Japan) was used to determine remaining concentration of heavy metals, which was done at the Department of Biological Sciences/University of Baghdad's Laboratories. The removal of heavy metal ions using coriander seeds was calculated under the influence of a variable $\mathrm{pH}$ of $(2-10)$, a contact time (0-180) min., dosage of coriander seeds (0.1-2) g/100ml, (50-300) rpm agitation speed and concentration of metals (10-200) $\mathrm{mg} / \mathrm{l}$. The percentage adsorption of $\mathrm{Pb}^{+2}, \mathrm{Zn}^{+2}$, and $\mathrm{Ni}^{+2}$ ions from the solution ( $\mathrm{R} \%$ ) and capacity of adsorption by coriander seeds qe $(\mathrm{mg} / \mathrm{g})$ were calculated according to Eq. (2) and Eq. (3), respectively [Anna et al., 2015].

$$
\begin{gathered}
R \%=\frac{\left(C_{o}-C_{e}\right)}{C_{e}} \times 100 \\
\mathrm{q}_{\mathrm{e}}=\frac{\mathrm{V}\left(\mathrm{C}_{\mathrm{o}}-\mathrm{C}_{\mathrm{e}}\right)}{\mathrm{m}}
\end{gathered}
$$

where: $C_{o}$ corresponds to the heavy metals ions initial concentration and

$C_{e}$ is the residual concentration after adsorption,

$V$ is the solution volume (L), $m$ is the mass of adsorbent (g).

\section{Characterization of coriander seeds}

In order to identify the functional groups of adsorbent (coriander seeds), a Fourier transform infrared spectroscopy (FTIR) is commonly used. In this study, a FTIR (IRPrestige21/Shimadzu, Europe) at Chemical Department/Collage of Science/Baghdad University, region $4000-400 \mathrm{~cm}^{-1}$ was used to determine the structural changes of the adsorbent before and after the sorption process. Field Emission Scanning Electron Microscope (FESEM) images were used to demonstrate surface morphology of the adsorbent (coriander seeds) by (Tescan Mira3, France).

\section{RESULTS AND DISCUSSION}

\section{Effect of $\mathrm{pH}$}

The $\mathrm{pH}$ is one of the most important factors to be studied and verified in any adsorption process to identify the ideal value that separates adsorption from precipitation. Many adsorption studies have shown the important effect of $\mathrm{pH}$ on the adsorption of heavy metals [Chen et al., 2019]. Figure 2 shows the effect of changing the $\mathrm{pH}$ in the range from (2 to 10) on the adsorption of $\mathrm{Pb}^{+2}, \mathrm{Zn}^{+2}$ and $\mathrm{Ni}^{+2}$ ions with adsorbent dosage of $0.5 \mathrm{~g} / 100 \mathrm{ml}$, a shaking time of $120 \mathrm{~min}$, initial metals concentration of $50 \mathrm{mg} / 1$ and $200 \mathrm{rpm}$ mixing speed at temperature $25 \pm 2^{\circ} \mathrm{C}$. The highest removal percentage of $\mathrm{Pb}^{+2}, \mathrm{Zn}^{+2}$ and $\mathrm{Ni}^{+2}$ ions at optimum pH 6 was $86.009 \%, 78.952 \%$, $58.559 \%$ respectively, and following that, it lowers as the $\mathrm{pH}$ rises. At lower $\mathrm{pH}$ values, the least sorption was observed, which could be because the hydrogen $\left(\mathrm{H}^{+}\right)$ions highly compete with metal ions for the coriander seeds surface active sites, and the complex between the acidic functional groups and metal ions is expected to be destabilized as the adsorbed metal ions is released into the solution. Moreover, an increase in $\mathrm{pH}$ induces metal ion precipitation on the adsorbent surface; this is because insoluble metal hydroxides begin to precipitate from solutions at higher $\mathrm{pH}$ values, making real sorption experiments difficult [Vafajoo et al., 2018]. 


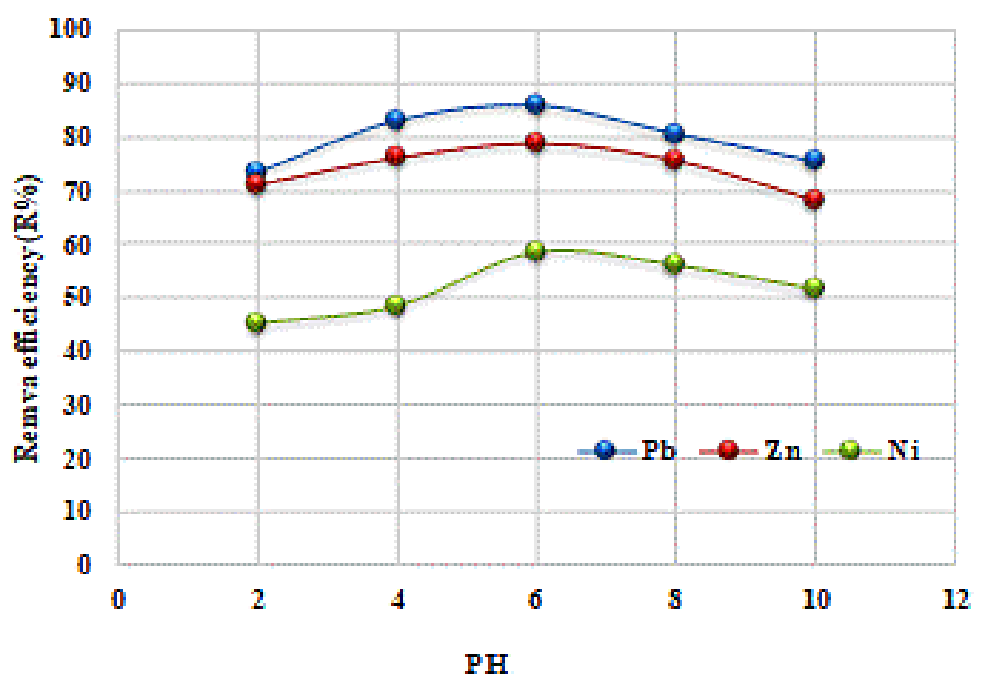

Figure 2. Effect of different $\mathrm{pH}$ on the removal efficiency of $\mathrm{Pb}^{+2}, \mathrm{Zn}^{+2}$ and $\mathrm{Ni}^{+2}$ ions by coriander seeds

\section{Effect of contact time}

The influence of contact time on adsorption of $\mathrm{Pb}^{+2}, \mathrm{Zn}^{+2}$ and $\mathrm{Ni}^{+2}$ ions on coriander seeds was investigated in the range of $0-180 \mathrm{~min}$. Other conditions were constant $(\mathrm{pH} 6$, dosage of adsorbents $0.5 \mathrm{~g} / 100 \mathrm{ml}$, initial metal concentrations $50 \mathrm{mg} / 1$, and $200 \mathrm{rpm}$ agitation speed at a temperature of $25 \pm 2{ }^{\circ} \mathrm{C}$ ). The effect of contact time on the removal of metal ions is shown in Figure 3. It was observed that the adsorption of $\mathrm{Pb}^{+2}, \mathrm{Zn}^{+2}$ and $\mathrm{Ni}^{+2}$ adsorption increased along with the contact time. The equilibrium was achieved at $105 \mathrm{~min}$, because there were plenty of wide surface areas available. The adsorption rate become very slow as contact time increases due to the saturation of active sites of coriander seeds at equilibrium state [Anna et al., 2015]. The maximum removal efficiencies for $\mathrm{Pb}^{+2}$,
$\mathrm{Zn}^{+2}$, and $\mathrm{Ni}^{+2}$ ions was $85.535 \%, 78.606 \%$, and $57.559 \%$ at optimum time $105 \mathrm{~min}$.

\section{Effect of coriander seeds dose}

The effect of coriander seeds dose on the removal of $\mathrm{Pb}^{+2}, \mathrm{Zn}^{+2}$, and $\mathrm{Ni}^{+2}$ ions was studied at varying dosage from (0.1 to 2$) \mathrm{g} / 100 \mathrm{ml}$, other parameters were constant $(\mathrm{pH} 6$, contact time $105 \mathrm{~min}$, initial concentration of metals $50 \mathrm{mg} / \mathrm{l}$, and $200 \mathrm{rpm}$ agitation speed at a temperature of $25 \pm 2{ }^{\circ} \mathrm{C}$ ). Figure 4 shows that the removal efficiency gradually increases along with the dose of coriander seeds up to $1 \mathrm{~g} / 100 \mathrm{ml}$. That is because more adsorption sites are available due to increased surface area, resulting in higher removal of heavy metals [Zhou et al., 2018]. A further increase in the quantity of coriander seeds will not have any significant effect on the removal

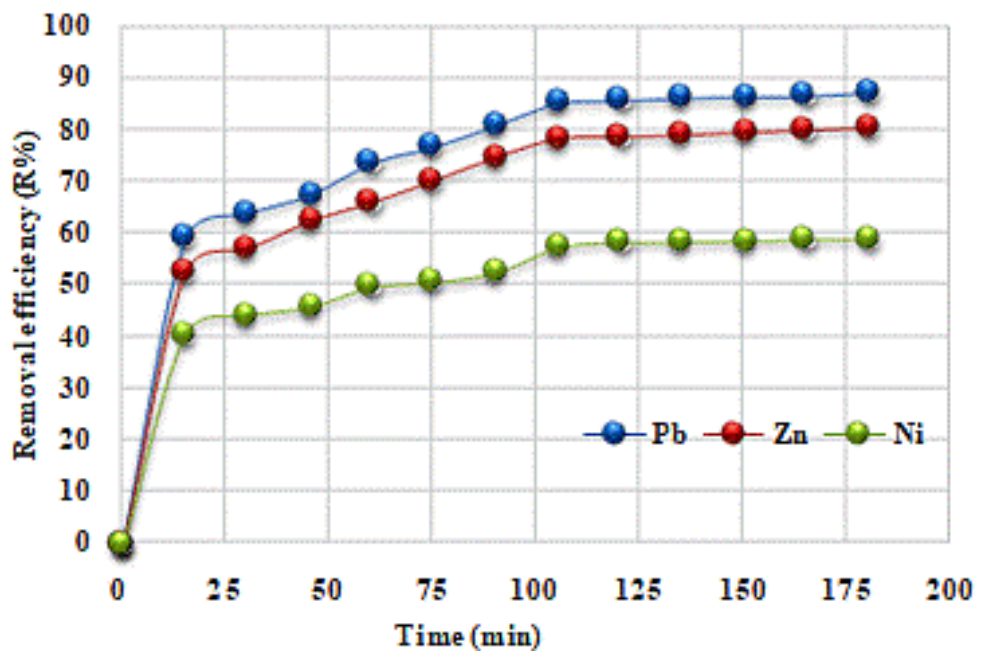

Figure 3. Effect of contact time on the removal efficiency of $\mathrm{Pb}^{+2}, \mathrm{Ni}^{+2}$ and $\mathrm{Zn}^{+2}$ by coriander seeds 


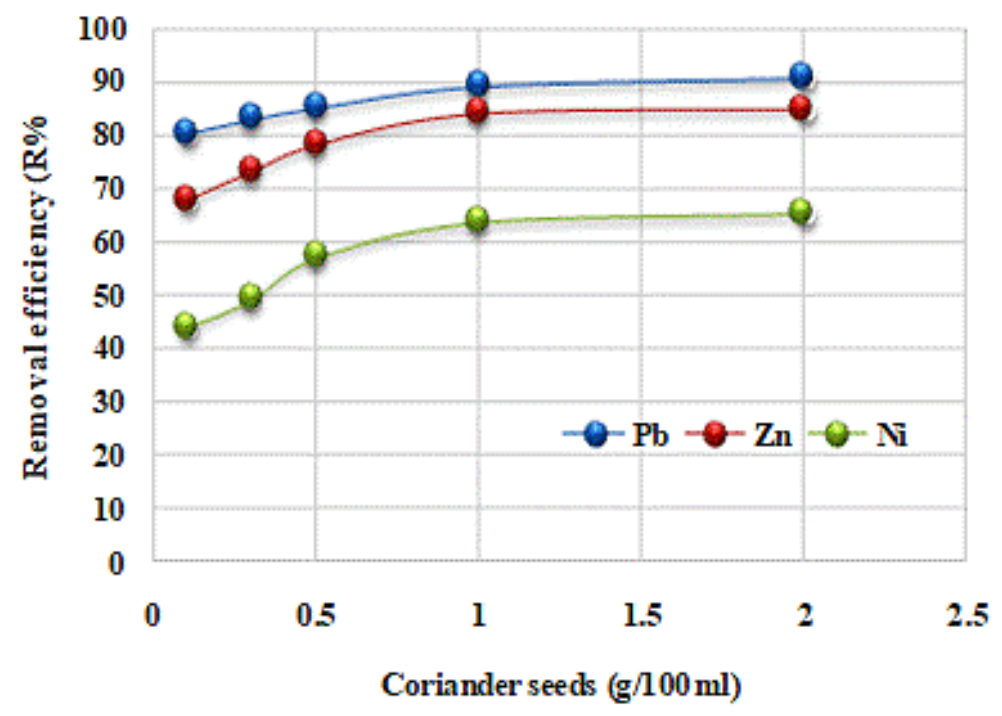

Figure 4. Effect of dosage on the removal efficiency of $\mathrm{Pb}^{+2}, \mathrm{Zn}^{+2}$ and $\mathrm{Ni}^{+2}$ by coriander seeds

due to the concentration of $\mathrm{Pb}^{+2}, \mathrm{Zn}^{+2}, \mathrm{Ni}^{+2}$ ions at the level of equilibrium condition between the solid and the solution phases [Kumar and Bilal, 2018]. The removal efficiency was $89.598 \%, 84.4$ $09 \%$ and $64.216 \%$ for $\mathrm{Pb}^{+2}, \mathrm{Zn}^{+2}$, and $\mathrm{Ni}^{+2}$ ions, respectively, at the optimum coriander seeds dosage $(1 \mathrm{~g} / 100 \mathrm{ml})$.

\section{Effect of initial heavy metal concentration}

The effect of various initial concentrations on $\mathrm{Pb}^{+2}, \mathrm{Zn}^{+2}$, and $\mathrm{Ni}^{+2}$ ions adsorption was investigated in the range of 10 to $200 \mathrm{mg} / \mathrm{l}$. Other conditions were $\mathrm{pH} 6$, dosage of adsorbents $1 \mathrm{~g} / 100 \mathrm{ml}$, contact time $105 \mathrm{~min}$ and mixing speed $200 \mathrm{rpm}$ at a temperature of $25 \pm 2{ }^{\circ} \mathrm{C}$. In Figure 5, it was obvious that as the initial concentration of the $\mathrm{Pb}^{+2}, \mathrm{Zn}^{+2}$, and $\mathrm{Ni}^{+2}$ ions increases from 10 to $200 \mathrm{mg} / \mathrm{l}$, the removal efficiency declines from $98.605 \%$ to $85.342 \%, 92.221 \%$ to $79.271 \%$, $85.412 \%$ to $65.634 \%$ for $\mathrm{Pb}^{+2}, \mathrm{Zn}^{+2}$, and $\mathrm{Ni}^{+2}$ ions, respectively. The percentage of metal ions removed dropped as the initial metals concentration increased from 10 to $200 \mathrm{mg} / \mathrm{l}$, according to the findings. A similar observation was noticed in other studies [Edathil et al., 2018]. Because the number of active adsorbent particle sites is restricted, only a limited number of metal ions can be absorbed. However, at high concentrations of metal ions, the active areas of the adsorbent particles are saturated [Parmar, 2013].

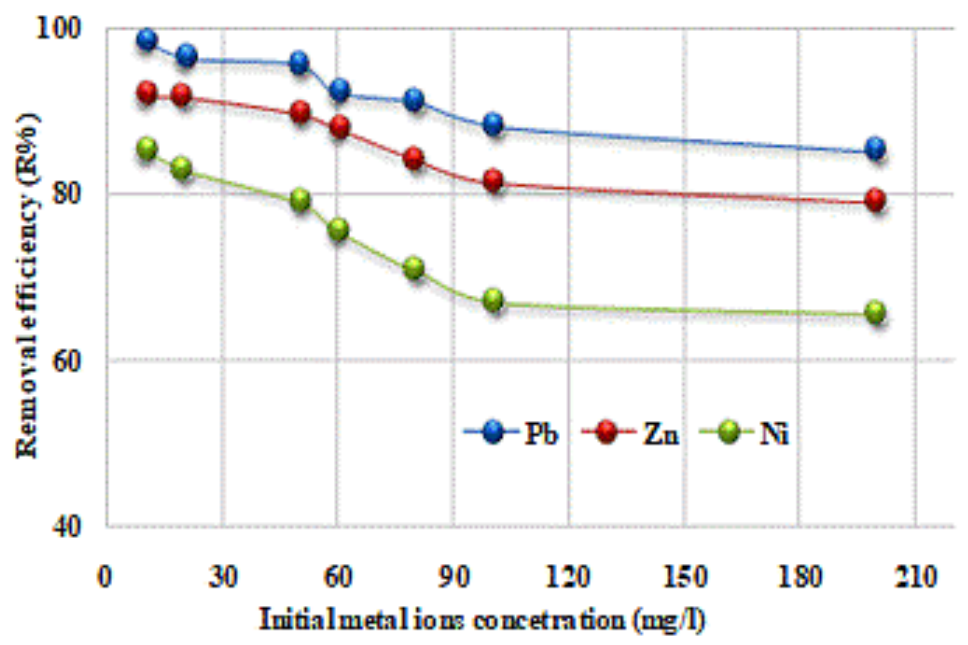

Figure 5. Effect of initial concentration on the removal efficiency of $\mathrm{Pb}^{+2} \mathrm{Ni}^{+2}$ and $\mathrm{Zn}^{+2}$ by coriander seeds. 


\section{Effect of agitation speed}

The agitation speed effect was investigated at different values, i.e. 50, 100, 200 and $300 \mathrm{rpm}$. Other conditions, including constant $\mathrm{pH}$, contact time, dosage, and initial metal concentration were 6, $105 \mathrm{~min}, 1 \mathrm{~g} / 100 \mathrm{ml}$, and $50 \mathrm{mg} / 1$, respectively, at a temperature of $25 \pm 2{ }^{\circ} \mathrm{C}$. From Figure 6 the removal efficiency was increased with the increasing in the agitation speed until reached $200 \mathrm{rpm}$ which reached $95.926 \%, 89.799 \%$, and $79.255 \%$ for $\mathrm{Pb}^{+2}, \mathrm{Zn}^{+2}$, and $\mathrm{Ni}^{+2}$ ions, respectively, further increased in agitation speed is then with no benefit. The reason may be that the increase in an agitation speed will caused breaking down of film layer formed on coriander seeds surface which will increase the chance of metal ions reaching the effective sites on the surface of the coriander seeds which in turn will increase the efficiency of adsorption [El Naggar et al., 2019].

\section{FTIR analysis for coriander seeds}

The functional groups found in coriander seeds were identified using the Fourier Transform Infrared Spectroscopy (FTIR) research. The FTIR spectra of $\mathrm{Pb}^{+2}, \mathrm{Zn}^{+2}$, and $\mathrm{Ni}^{+2}$ ions before and after sorption are shown in Figure 7. The coriander seeds before adsorption displayed a number of peaks pertaining to different functional groups. The wide band observed at $3402.43 \mathrm{~cm}^{-1}$ indicates free and intermolecular bonds $(\mathrm{O}-\mathrm{H})$ of the hydroxyl group. In turn, the band at 2926.01 $\mathrm{cm}^{-1}$ was assigned as the stretching vibration of the C-H (carboxylic) groups that were present in the lignin structure [Hussein and Jasim, 2019]. The band observed at approximately 1625 and $1510 \mathrm{~cm}^{-1}$ indicated that $(\mathrm{C}=\mathrm{O}$ stretch $)$ amides, and $(\mathrm{C}=\mathrm{C})$ bonds of aromatic rings were present, respectively. The peak observed at $1745 \mathrm{~cm}^{-1}$ is the stretching vibration of amides $(\mathrm{C}=\mathrm{O}$ aldehyde stretch). The band at $1460.11 \mathrm{~cm}^{-1}$ indicated (C-O)

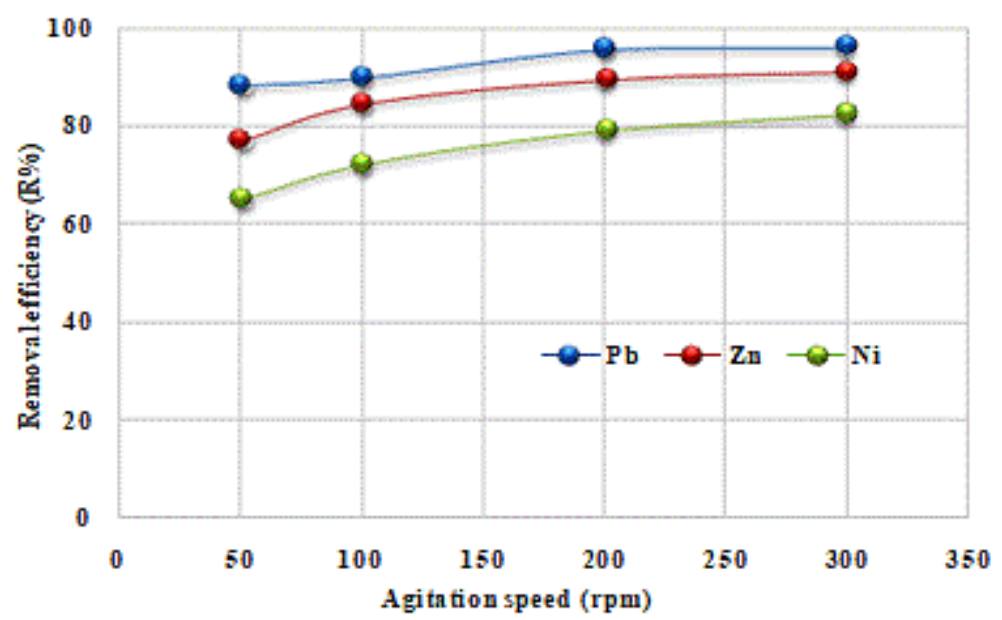

Figure 6. Effect of agitation speed on the removal efficiency of $\mathrm{Pb}^{+2}, \mathrm{Ni}^{+2}$ and $\mathrm{Zn}^{+2}$ by coriander seeds.

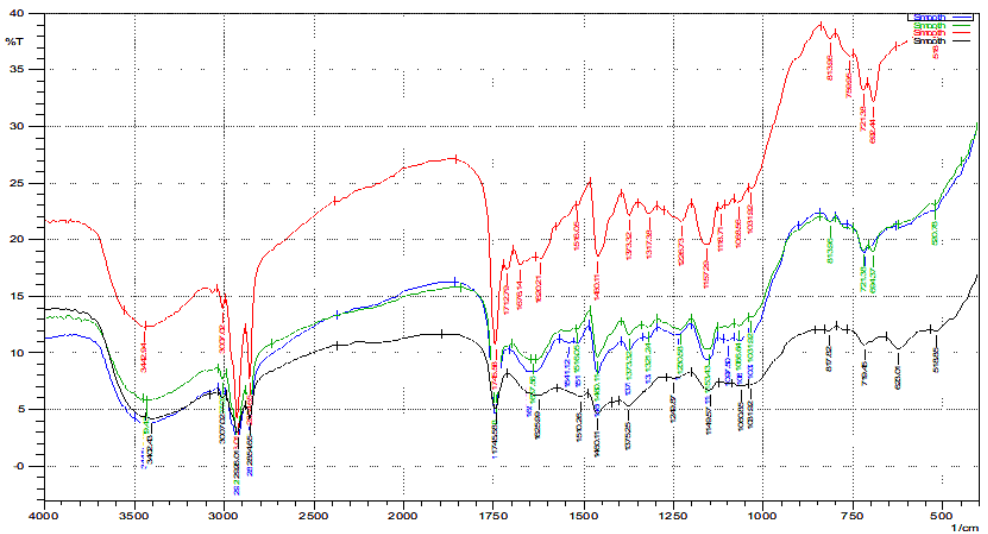

Figure7. FTIR spectrums of coriander seeds (black line ) before adsorption, (red line) coriander after the adsorption of $\mathrm{Pb}^{+2}$ ions, (green line) coriander after the adsorption of $\mathrm{Zn}^{+2}$ ions, (blue line) coriander after adsorption $\mathrm{Ni}^{+2}$ ions. 
Table 1. Functional groups before and after coriander adsorption with $\mathrm{Pb}^{+2}, \mathrm{Zn}^{+2}$, and $\mathrm{Ni}^{+2}$ ions

\begin{tabular}{|l|cc|cc|}
\hline \multicolumn{1}{|c|}{ Assignment functional groups } & Before adsorption & $\begin{array}{c}\text { After adsorption } \\
\text { of } \mathrm{Pb}+2 \text { ions }\end{array}$ & $\begin{array}{c}\text { After adsorption } \\
\text { of } \mathrm{Zn+2} \text { ions }\end{array}$ & $\begin{array}{c}\text { After adsorption } \\
\text { of } \mathrm{Ni}+2 \text { ions }\end{array}$ \\
\hline (O-H) of hydroxyl group & 3402.43 & 3442.94 & 3429.43 & 3441.01 \\
\hline (C-H) carboxylic groups & 2926.01 & 2926.01 & 2926.01 & 2926.01 \\
Amides (C=O aldehyde stretch) & 1745.58 & 1745.58 & 1745.58 & 1745.58 \\
\hline Amides (C=O stretch) & 1625.49 & 1620.21 & 1637.56 & 1651.07 \\
C=C Aromatic stretch & 1510.26 & 1516.05 & 1516.05 & 1516.05 \\
\hline C-O (primary alcohol) & 1460.11 & 1460.11 & 1460.11 & 1460.11 \\
Nitro aliphatic group (-NO $\left.{ }_{2}\right)$ & 1375.25 & 1317.38 & 1373.32 & 1321.24 \\
\hline C-O (alcohol) group & 1249.87 & 1226.73 & 1230.58 & 1236.37 \\
C-O (alcohol) group & 1149.57 & 1157.29 & 1153.43 & 1151.50 \\
\hline Aromatic (C-H bend) & 719.45 & 759.95 & 721.38 & 719.45 \\
Alkyl halides [(C-Br) and (C-I)] & 518.85 & 518.85 & 520.78 & - \\
\hline
\end{tabular}

primary alcohol [Wang et al., 2018]. The peak at 1375.25 represents $\left(-\mathrm{NO}_{2}\right)$ the aliphatic group. The peaks at $1249.87,1149.57$ indicated the C-O (alcohol) group. The band at $719.45 \mathrm{~cm}^{-1}$ was corresponded to the aromatic group (C-H bond), and the band at 518.85 represents the $(\mathrm{C}-\mathrm{Br})$ and (C-I) alkyl halides group [Malakahmad et al., 2016]. The adsorption of heavy metal ions on the cell surfaces of coriander seeds was attributed to functional groups such as amides, aromatic, alcohol, carboxylic acid, and hydroxyl. The observed peaks and its description are shown in Table1.

\section{FESEM analysis}

FESEM is a technique for studying the surface structure of an adsorbent before and after adsorption. It is also applied to investigate, e.g. particle shape, porosity nature, and proper size distribution of the adsorbent [Hussein and Jasim, 2019]. The surface morphology images of the adsorbent with $\mathrm{Pb}^{+2}, \mathrm{Zn}^{+2}$, and $\mathrm{Ni}^{+2}$ ions are shown in Figure 8 b, c and d. In Figure $7 a$, the presence of particles agglomerates with irregular shape can be seen in the FESEM scan of the adsorbent surface [Elabbas et al., 2016]. The surface becomes smooth and shiny with filled pore structures after heavy metal ion adsorption, likely due to physic-chemical interaction between the functional groups on the surface and the heavy metal ions [Amin et al., 2017]. The shape of the surface has altered after absorbing $\mathrm{Pb}^{+2}, \mathrm{Zn}^{+2}$, and $\mathrm{Ni}^{+2}$ ions, indicating that the adsorption process of ions on the surface of the adsorbent material has occurred.

\section{Adsorption Isotherm}

The equilibrium approach was studied using the Langmuir and Freundlich models. In order to study homogenous surface adsorption, the Langmuir model is used. The process is based on that there is saturated mono layer of solute on the outer surface of the adsorption, adsorption energy constant and adsorption occur at homogenous site. The Langmuir model described by Eq. 4 [Ramesh et al., 2013].

$$
q_{e}=\frac{q_{m} K_{L} C_{e}}{1+K_{L} C_{e}}
$$

where: $C_{e}$ is the equilibrium of metal ions concentration in the solution $(\mathrm{mg} / \mathrm{l})$,

$q_{e}$ is amount of metal ions per unite mass of adsorbent at equilibrium $(\mathrm{mg} / \mathrm{g})$,

$q_{m}$ is the maximum adsorption capacity on the adsorbent surface $(\mathrm{mg} / \mathrm{g})$ and

$K_{L}$ is there a relationship between the Langmuir constant and energy adsorption capacity $(1 / \mathrm{mg})$. The Langmuir equation can be fitted with a straight line equation, as follows [Mohammed et al., 2016].

$$
\frac{C_{e}}{q_{e}}=\frac{1}{K_{L} q_{m}}+\frac{C_{e}}{q_{m}}
$$

The values of $\mathrm{K}_{\mathrm{L}}$ and $\mathrm{q}_{\mathrm{m}}$ were calculated from the slope of the line and intercept that is sketched between of $\mathrm{C}_{\mathrm{e}} / \mathrm{q}_{\mathrm{e}}$ and $\mathrm{C}_{\mathrm{e}}$.

The Freundlich equation is used to study the adsorption occur at multilayer heterogeneous surfaces. The Freundlich model can be expressed in the following way [Parmar, 2013]. 

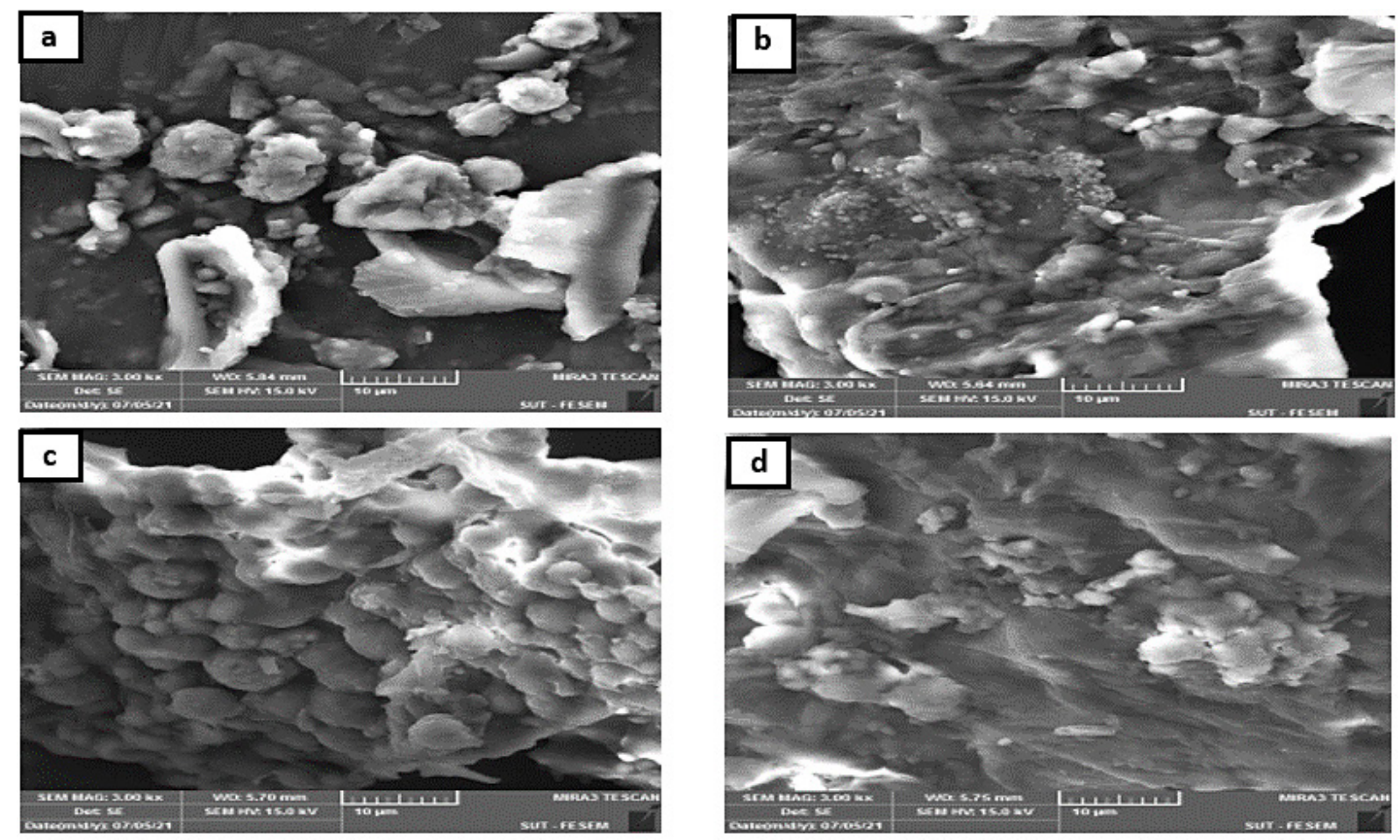

Figure 8. FESEM image of (a) coriander seeds before adsorption, (b) coriander seeds after adsorption with $\mathrm{Pb}^{+2}$ ions, (c) coriander seeds after adsorption with $\mathrm{Zn}^{+2}$ ions, and (d) coriander seeds after adsorption with $\mathrm{Ni}^{+2}$ ions.

$$
\ln q_{e}=\ln K_{f}+\frac{1}{n} \ln C_{e}
$$

where: $K_{f}$ represents the capacity of adsorption and $\mathrm{n}$ is the intensity factor of the adsorption process. The values of $\mathrm{K}_{\mathrm{f}}$ and $\mathrm{n}$ were calculated from the slope of the line and intercept that is sketched between of $\operatorname{lnq}_{\mathrm{e}}$ and $\operatorname{lnC}_{\mathrm{e}}$.

The parameters for the Langmuir and Freundlich models were specified by fitting the experimental data to the isotherm models are shown in Figures 9 a, b. Table 2 shows all parameters with the correlation coefficients $\left(\mathrm{R}^{2}\right)$, the values of the correlation coefficient for the Langmuir are $0.8461,0.826,0.8062$ for $\mathrm{Pb}^{+2}, \mathrm{Zn}^{+2}$, and $\mathrm{Ni}^{+2}$ ions, respectively, and for Freundlich models they are $0.9864,0.988,0.991$ for $\mathrm{Pb}^{+2}, \mathrm{Zn}^{+2}$, and $\mathrm{Ni}^{+2}$ ions, respectively; thus, the Freundlich model represents better adsorption than the Langmuir model dependent on the values of correlation coefficients.

\section{Adsorption Kinetics Models}

The pseudo-first-order and pseudo-secondorder models were used to study the kinetics of heavy metals on to coriander seeds. When the correlation coefficient $\left(\mathrm{R}^{2}\right)$ value is high and close to one, the process is considered successful [Amin et al., 2017].

The pseudo-first-order model is given in Eq.7 [Mohammed et al., 2016]

$$
\ln \left(q_{e}-q_{t}\right)=\ln q_{e}-k_{1} t
$$

where: $q_{e}$ is the amount of metal ions sorbed at equilibrium $(\mathrm{mg} / \mathrm{g})$,

Table2. Parameters of isotherm for $\mathrm{Pb}^{+2}, \mathrm{Zn}^{+2}$, and $\mathrm{Ni}^{+2}$ ions onto coriander seeds

\begin{tabular}{|cc|cc|cc|cc|}
\hline \multicolumn{4}{c}{ Langmuir } & \multicolumn{4}{c|}{ Freundlich } \\
\hline Parameters & $\mathrm{Pb}^{+2}$ & $\mathrm{Zn}^{+2}$ & $\mathrm{Ni}^{+2}$ & Parameters & $\mathrm{Pb}^{+2}$ & $\mathrm{Zn}^{+2}$ & $\mathrm{Ni}^{+2}$ \\
\hline $\mathrm{qm}(\mathrm{mg} / \mathrm{g})$ & 19.763 & 22.883 & 19.011 & $\mathrm{Kf}(\mathrm{mg} / \mathrm{g})$ & 2.6966 & 1.1763 & 1.4489 \\
$\mathrm{KL}(\mathrm{l} / \mathrm{mg})$ & 0.1216 & 0.0403 & 0.0233 & $\mathrm{n}$ & 1.9084 & 1.4388 & 1.4562 \\
\hline $\mathrm{R} 2$ & 0.8461 & 0.826 & 0.8062 & $\mathrm{R} 2$ & 0.9864 & 0.988 & 0.991 \\
\hline
\end{tabular}



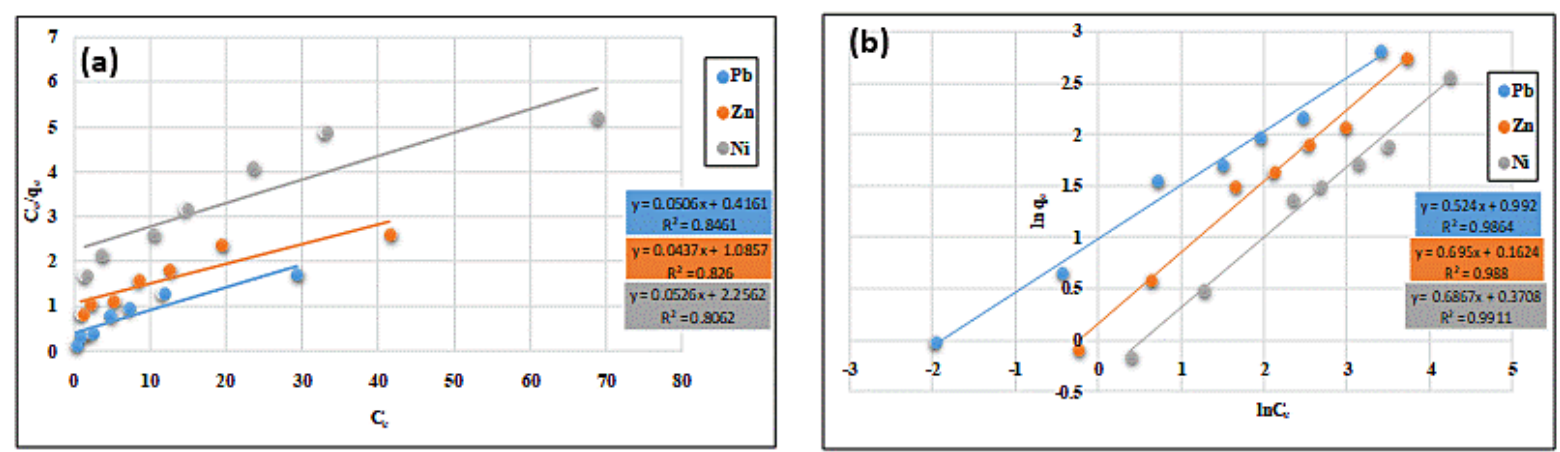

Figure 9. Sorption isotherm models for $\mathrm{Pb}^{+2}, \mathrm{Zn}^{+2}$, and $\mathrm{Ni}^{+2}$ on coriander seeds (a) Langmuir isotherm model and (b) Frendlich isotherm model
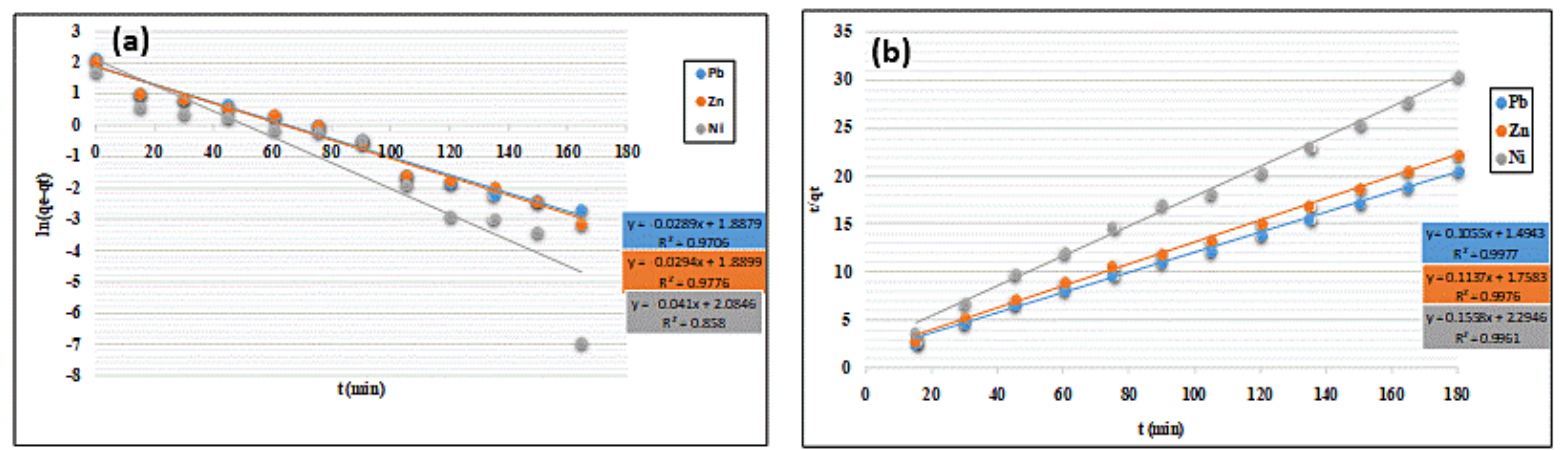

Figure10. Sorption kinetic model of $\mathrm{pb}^{+2}, \mathrm{Zn}^{+2}$, and $\mathrm{Ni}^{+2}$ onto coriander seeds (a) Pseudofirst-order kinetic model, and (b) Pseudo-second-order kinetic model

$q_{t}$ the amount of metal ions sorbed at time $\mathrm{t}(\mathrm{mg} / \mathrm{g}), \mathrm{k}_{1}$ is the pseudo-first-order sorption equilibrium rate constant $(1 / \mathrm{min})$;

$k_{1}$ and $q_{e}$ are determined from slope of the line and intercept by plotting between of $\operatorname{Ln}\left(q_{e}-q_{t}\right)$ versus $t$ as shown in Figure 10 a.

The pseudo-second-order model is given in Eq. 8 [El Naggar et al., 2019].

$$
\frac{t}{q_{t}}=\frac{1}{k_{2} q_{e}^{2}}+\frac{t}{q_{e}}
$$

where: $k_{2}$ is the pseudo-second -order sorption equilibrium rate constant $(1 / \mathrm{min})$. The values of $\mathrm{k}_{2}$ and $\mathrm{q}_{\mathrm{e}}$ are determined from slope of the line and intercept by plotting between of $t / q t$ versus $t$, as shown in Figure $10 \mathrm{~b}$.
Table 3 shows the experimental data and calculated parameters. The values of correlation coefficients $\left(\mathrm{R}^{2}\right)$ better fit of pseudo-second-order kinetic with experiment data compared to pseudo-first-order. The value of experimental $\mathrm{q}_{\mathrm{e}}$ was fitted to $\mathrm{q}_{\mathrm{e}}$ calculated pseudo-second-order compared with pseudo-first-order model. This demonstrated that chemisorption was involved in the sorption process [Amin et al., 2017].

\section{CONCLUSIONS}

The feasibility of using coriander seeds as a low-cost adsorbent for the removal of $\mathrm{Pb}^{+2}, \mathrm{Zn}^{+2}$ and $\mathrm{Ni}^{+2}$ ions from wastewater was investigated in this study. Coriander seeds were found to be a

Table (3). Parameters of kinetic for $\mathrm{Pb}^{+2}, \mathrm{Zn}^{+2}$, and $\mathrm{Ni}^{+2}$ ions onto coriander seeds

\begin{tabular}{|cc|cc|cc|cc|}
\hline \multicolumn{4}{|c|}{ Pseudo-first-order } & \multicolumn{3}{c|}{ Pseudo-second-order } \\
\hline Parameters & $\mathrm{Pb}^{+2}$ & $\mathrm{Zn}^{+2}$ & $\mathrm{Ni}^{+2}$ & Parameters & $\mathrm{Pb}^{+2}$ & $\mathrm{Zn}^{+2}$ & $\mathrm{Ni}^{+2}$ \\
\hline $\mathrm{q}_{\text {e(exp.) }}(\mathrm{mg} / \mathrm{g})$ & 8.7628 & 8.0722 & 5.9098 & $\mathrm{q}_{\text {e(exp.) }}(\mathrm{mg} / \mathrm{g})$ & 8.7628 & 8.0722 & 5.9098 \\
$\mathrm{k}_{1}\left(\mathrm{~min}^{-1}\right)$ & 0.0289 & 0.0294 & 0.041 & $\mathrm{k}_{2}\left(\mathrm{~min}^{-1}\right)$ & 0.00748 & 0.00735 & 0.01058 \\
\hline $\mathrm{q}_{\mathrm{e}(\text { cal. })}(\mathrm{mg} / \mathrm{g})$ & 6.6055 & 6.6187 & 8.0414 & $\mathrm{q}_{\mathrm{e}(\text { (cal.) }}(\mathrm{mg} / \mathrm{g})$ & 9.4787 & 8.7951 & 6.4185 \\
$\mathrm{R}^{2}$ & 0.9706 & 0.9776 & 0.858 & $\mathrm{R}^{2}$ & 0.9977 & 0.9976 & 0.9961 \\
\hline
\end{tabular}


good efficient sorbent for removing these heavy metals ions from wastewater under the following optimum conditions: initial concentration $50 \mathrm{mg} / \mathrm{l}, \mathrm{pH}$ 6, contact time $105 \mathrm{~min}$., coriander seeds dosage $1 \mathrm{~g} / 100 \mathrm{ml}$, and agitation speed $200 \mathrm{rpm}$ at a temperature of $25 \pm 2{ }^{\circ} \mathrm{C}$. The batch experiments results showed that the maximum removal percentages achieved under ideal conditions for $\mathrm{Pb}^{+2}, \mathrm{Zn}^{+2}$ and $\mathrm{Ni}^{+2}$ ions were $95.926 \%$, $89.799 \%$ and $79.255 \%$, respectively. The FTIR and FESEM analyses revealed that the functional groups on the surface of coriander seeds were detected and the morphology of the surface was studied. The Langmuir and pseudo-second-order sorption isotherms were shown to have the best correlation for sorption of $\mathrm{Pb}^{+2}, \mathrm{Zn}^{+2}$, and $\mathrm{Ni}^{+2}$ ions onto coriander seeds, and it was discovered that coriander seeds can be used as an alternative eco-friendly and effective adsorbent for the treatment of wastewater containing metal ions.

\section{Acknowledgments}

The author would like to thank the Mustansiriyah university (www.uomustansiriyah.edu.iq) Baghdad - Iraqfor its support in the present work.

\section{REFERENCES}

1. Abdou SaidA., Reda R.M., and Abd El-Hady H.M. 2021. Overview of herbal biomedicines with special reference to coriander (Coriandrum sativum) as new alternative trend for the development of aquaculture. Egyptian Journal of Aquatic Biology and Fisheries, 25 (2), 539-550.

2. Al-Obaidy A.M.J., Al-Janabi Z.Z. and Al-Mashhady A.A.M. 2016. Distribution of some heavy metals in sediments and water in Tigris River. Journal of Global Ecology and Environment, 4 (3), 140-146.

3. Amin M.T., Alazba A.A. and Amin M.N. 2017. Absorption behaviours of copper, lead, and arsenic in aqueous solution using date palm fibres and orange peel: kinetics and thermodynamics. Polish Journal of Environmental Studies, 26 (3), 543-557.

4. Anna B.,Kleopas M., Constantine S., Anestis F. andMaria B.2015. Adsorption of Cd (II), Cu (II), Ni (II) and $\mathrm{Pb}$ (II) onto natural bentonite: study in monoand multi-metal systems. Environmental Earth Sciences, 73 (9), 5435-5444.

5. Chatterjee S., Sivareddy I. and De S. 2017. Adsorptive removal of potentially toxic metals (cadmium, copper, nickel and zinc) by chemically treated laterite: single and multicomponent batch and column study. Journal of Environmental Chemical Engineering, 5 (4), 3273-3289.

6. Edathil A.A., Shittu I., Zain H.J., Banat F. and Abu haija M. 2018. Novel magnetic coffee waste nanocomposite as effective bioadsorbent for $\mathrm{Pb}$ (II) removal from aqueous solutions. Journal of Environmental Chemical Engineering, 6 (2), 2390-2400.

7. Elabbas S., Mandi L., Berrekhis F., Pons M.N., Leclerc J.P. and Ouazzani N. 2016. Removal of $\mathrm{Cr}$ (III) from chrome tanning wastewater by adsorption using two natural carbonaceous materials: eggshell and powdered marble. Journal of environmental management, 166, 589-595.

8. El Naggar A.M.A., Ali M.M., Abedl Maksoud S.A., Taha M.H., Morshedy A.S. and Elzoghby A. 2019. Waste generated bio-char supported co-nanoparticles of nickel and cobalt oxides for efficient adsorption of uranium and organic pollutants from industrial phosphoric acid. Journal of Radioanalytical and Nuclear Chemistry, 320(3), 741-755.

9. Ergüvenerler F., Targan Ş. and Tirtom V.N. 2020. Removal of lead from aqueous solutions by low cost and waste biosorbents (lemon, bean and artichoke shells). Water Science and Technology, 81(1), 159-169.

10. Faisal A. A. H.,Kassim W. M. S., and Hussein T. K. 2011. Influence of clay lens on migration of light non aqueous phase liquid in unsaturated zone, Journal of Environmental Engineering, 137 (1), 9-14.

11. Foroughi-DahrM., Abolghasemi H., Esmaili M., Shojamoradi A. and Fatoorehchi H. 2015. Adsorption characteristics of congo red from aqueous solution onto tea waste. Chemical Engineering Communications, 202 (2), 181-193.

12. Hussein T. K. and Jasim N. A. 2019. Removal of crystal violet and methylene blue from synthetic industrial wastewater using fennel seed as an adsorbent. Journal of Engineering Science and Technology, 14(5), 2947-2963.

13. Jia Y., Zhang Y., Fu J., Yuan L., Li Z., Liu C., Zhao D. and Wang X. 2019. A novel magnetic biochar/MgFe-layered double hydroxides composite removing $\mathrm{Pb}^{+2}$ from aqueous solution: isotherms, kinetics and thermodynamics. Colloids and Surfaces A: Physicochemical and Engineering Aspects, 567(20), 278-287.

14. Kavand M., Kaghazchi T. and Soleimani M. 2014. Optimization of parameters for competitive adsorption of heavy metal ions $\left(\mathrm{Pb}^{+2}, \mathrm{Ni}^{+2}, \mathrm{Cd}^{+2}\right)$ onto activated carbon. Korean journal of chemical engineering, 31 (4), 692-700.

15. Kumar M. R. and Bilal B. 2018. Removal of congo red from dye wastewater using adsorption. International Journal of Engineering and Techniques, 4 (1), 18-27.

16. Mahanty S., Chatterjee S., Ghosh S., Tudu P., Gaine T., Bakshi M., Das S., Das P., Bhattacharyya S., 
Bandyopadhyay S. and Chaudhuri P. 2020. Synergistic approach towards the sustainable management of heavy metals in wastewater using mycosynthesized iron oxide nanoparticles: biofabrication, adsorptive dynamics and chemometric modeling study. Journal of Water Process Engineering, 37, 101-426.

17. Malakahmad A., Tan S. and Yavari S.2016. Valorization of wasted black tea as a low-cost adsorbent for nickel and zinc removal from aqueous solution. Journal of Chemistry, Article ID 5680983, 1-8

18. Mohammed A.A., Abed F.I. and Al-Musawi T.J. 2016. Biosorption of $\mathrm{Pb}$ (II) from aqueous solution by spent black tea leaves and separation by flotation. Desalination and Water Treatment, 57 (5), 2028-2039.

19. Mohammed N.M.S. and Salim H.A.M. 2017. Adsorption of $\mathrm{Cr}(\mathrm{Vi})$ ion from aqueous solutions by solid waste of potato peels. Science Journal of University of Zakho, 5 (3), 254-258.

20. Mohan S.M. 2014. Simultaneous adsorption and biodegradation process in a SBR for treating wastewater containing heavy metals. Journal of Environmental Engineering, 140 (4), 4014008.

21. Parmar K. 2013. Removal of cadmium from aqueous solution using cobalt silicate precipitation tube (CoSPT) as adsorbent. International journal of Science Invention Today, 2 (3), 204-215.

22. Qassim F.M. 2013. Removal of heavy metal from water by sorptive flotation. M. Sc. Thesis, Baghdad University, Iraq.

23. Osińska M. 2017. Removal of lead (II), copper (II), cobalt (II) and nickel (II) ions from aqueous solutions using carbon gels. Journal of Sol-gel Science and Technology, 81 (3), 678-692.

24. Ouass A., Ismi I., Elaidi H., Lebkiri A., Cherkaoui M. andRifi E.H. 2017. Mathematical modeling of the adsorption of trivalent chromium by the sodium polyacrylate beads. Journal of Material and Environmental Sciences, 8, 3448-3456.

25. Ramesh S.T., Rameshbabu N., Gandhimathi R., Kumar M.S. and Nidheesh P.V. 2013. Adsorptive removal of $\mathrm{Pb}$ (II) from aqueous solution using nano-sized hydroxyapatite. Applied Water Science, 3(1), 105-113.

26. Rao R.A.K. and Kashifuddin M. 2012. Adsorption properties of coriander seed powder (Coriandrum sativum): extraction and pre-concentration of $\mathrm{Pb}$ (II), $\mathrm{Cu}$ (II) and $\mathrm{Zn}$ (II) ions from aqueous solution. Adsorption Science and Technology, 30(2), 127-146.
27. Ray J., Jana S., Bhanja S.K. and Tripathy T. 2018. Efficient removal of Co(II), Ni(II), and $\mathrm{Zn}(\mathrm{II})$ metal ions from binary and ternary solutions using a $\mathrm{pH}$ responsive bifunctional graft copolymer. Colloid and Polymer Science, 296 (8), 1275-1291.

28. Rodiguez M.H., Yperman J., Carleer R., Maggen J., Dadi D., G ryglewicz G., Bruggen B.V.D., Hernandez J.F. andCalvis A.O. 2018. Adsorption of Ni (II) on spent coffee and coffee husk based activated carbon. Journal of Environmental Chemical Engineering, 6 (1), 1161-1170.

29. Vafajoo L., Cheraghi R., Dabbagh R. and Mckay G. 2018. Removal of cobalt (II) ions from aqueous solutions utilizing the pre-treated 2-Hypnea Valentiae algae: Equilibrium, thermodynamic, and dynamic studies. Chemical Engineering Journal, 331, 39-47.

30. Yadav V.K., Ali D., Khan S.H ., Gnanamoorthy G., ChoudharyN., Yadav K.K., Thai V.N., Hussain S. A. and Manhrdas S. 2020. Synthesis and characterization of amorphous iron oxide nanoparticles by the sonochemical method and their application for the remediation of heavy metals from wastewater. Nanomaterials, 10 (8), 15-51.

31. Wang G., Zhang S., Yao P., Chen Y., Xu X., Li T., and Gong G. 2018. Removal of $\mathrm{Pb}$ (II) from aqueous solutions by Phytolacca americana L. biomass as a low cost biosorbent. Arabian Journal of Chemistry, 11, 99-110.

32. Zeković Z. Kaplan M., Pavlic B., Olgun E.O., Vladic J., Canli O. and Vidovic S. 2016. Chemical characterization of polyphenols and volatile fraction of coriander (Coriandrum sativum L.) extracts obtained by subcritical water extraction. Industrial Crops and Products, 87, 54-63.

33. Zhi-Liang C., Jain-Qiang Z., Ling H., Zhi-Hui Y., Zho-Jun L. and Min-Chao L. 2019. Removal of Cd and $\mathrm{Pb}$ with biochar made from dairy manure at low temperature. Journal of Integrative Agriculture, 18(1), 201-210.

34. Zhou X., Yaochi L., Jianjun Z., Jing G., Jialin R. and Fang Z. 2018. Efficient removal of lead from aqueous solution by urea-functionalized magnetic biochar: Preparation, characterization and mechanism study. Journal of the Taiwan Institute of Chemical Engineers, 91, 457-467. 